\title{
COURTS AND THE MEDIATION OF PUBLIC RESOURCE (AB)USE DURING ELECTIONS IN MALAWI
}

\author{
Mwiza Jo Nkhata \\ Mwiza Jo Nkhata is extraordinary professor, Free State Centre for Human \\ Rights, University of the Free State
}

\begin{abstract}
The (ab)use of public resources during elections in Malawi is a recurrent phenomenon. The judicial mediation of the (ab)use of public resources has, however, not been extensive. In instances where courts have intervened, their pronouncements have done little to stem the practice, especially by incumbents. This paper interrogates the judicial regulation of the (ab)use of public resources during elections in Malawi. Among other things, it establishes that state media remains one of the most highly contested resources during elections. The paper demonstrates that the judicial understanding of public resources is narrow and may shield politicians from censure. In addition, political actors in Malawi seem interested in questioning the (ab)use of public resources only in the period immediately preceding polling without concern about any (ab)use during the rest of the electoral cycle.
\end{abstract}

Keywords: elections, public resources, courts, party funding, civil society, electoral cycle

\section{INTRODUCTION}

Elections are a process and not an isolated event. They are often evaluated by whether they are free and fair. There are, however, a myriad of elements that contribute towards the freeness and fairness of an election. Elections are also a resource-intense activity. For candidates, the chances of success are often related to the resources at their disposal. While access to resources alone may not determine the outcome of an election, it remains a critical influence on the result. The nature of the resources to which a candidate has access may also have a bearing on how free and fair the election is, since access to some resources may distort the playing field for contestants. 
Although polling day is the most visible part of the electoral cycle, much happens between, during and after elections that can have a critical bearing on the outcome (Ronceray \& Byiers 2019, p. 4). The extent to which an election is free and fair therefore requires a holistic perspective which scrutinises the activities of candidates and their political parties during the entire electoral cycle. Only in this way can it be determined whether or not a candidate or a political party has an unfair advantage by, for example, having illicit recourse to public resources.

The (ab)use of public resources during elections has often been analysed in the context of the advantages and disadvantages that it confers. The advantages that incumbency confers on political actors have been well explored (MacDonald 2014 , p. 2). These frequently stem from the access to public resources that incumbents acquire by virtue of their positions. Conversely, incumbency can also be a disadvantage in an election (MacDonald 2014, pp. 1-2). In the Malawian context, for example, Joyce Banda was arguably burdened by the excesses of her regime when she lost the presidency in 2015.

At present, an incumbent's access to public resources is the common precursor to the $(\mathrm{ab})$ use of public resources during elections and is a threat to the integrity of any electoral process (Helle \& Rakner 2014, p. 161). The legitimacy and integrity of an election in turn depend on the perception of both the electorate and candidates that the process has been conducted in a manner that does not guarantee specific outcomes in advance (Rakner \& Svasand 2005, p. 2). A level playing field is critical for securing the legitimacy and integrity of elections, and this includes guaranteeing fair and equitable access to state resources by all contestants (Mbaya 2004, pp. 85-86).

The (ab)use of public resources during elections must be viewed broadly since it may include any use of public resources in a manner that confers an advantage to a candidate or political party not afforded to other candidates or political parties (Transparency International 2017). Although the (ab)use of public resources tends to acquire prominence in the run-up to polling, this can take place at any time during the electoral cycle. Further, although it is easy to allege such (ab)uses, it is difficult to substantiate them because such incidents manifest themselves in multifarious, sometimes subtle forms. The conflation of official and unofficial duties by incumbents also obscures matters.

The (ab)use of public resources during elections is widespread across the world, including in Africa. Research on the subject, especially within the Southern African Development Community (SADC) to which Malawi belongs, is sparse (Matlosa \& Mbaya 2004, p. 47). While acknowledging the continental and global dimensions of the problem, this paper's focus is specifically on the judicial mediation of the (ab)use of public resources during elections in Malawi. Although Malawian case law on the subject is very limited, the paper assumes that for as 
long as the legal order established by the Constitution of the Republic of Malawi 1994 (the Constitution) remains in place, Malawi is welded to a democratic system of governance. This commitment to democratic governance demands that Malawi must hold periodic, free and fair elections. The conduct of past elections in Malawi strongly suggests that the problem of (ab)using public resources during elections is likely to be recurrent.

This paper interrogates judicial developments in Malawi relating to the (ab) use of public resources during elections. The following section crafts a framework for understanding the topic and is followed by a situation analysis of this (ab)use and the judicial treatment of such cases. The penultimate section isolates issues requiring further attention, ending with the conclusion.

\section{ELECTIONS AND THE (AB)USE OF PUBLIC RESOURCES}

Public or state resources refer to any resources belonging to the government at all levels of the administration (Ohman 2011, p. 1). Although public resources are sometimes understood as being exclusively financial, they can take many forms and are categorised into four broad groups: financial, institutional, regulatory and enforcement resources (Ohman 2011, pp. 1-2). Financial resources cover monetary resources at the disposal of the state, including publicly- owned state institutions. Institutional resources are non-monetary material and personnel resources available to the state, including publicly-owned media and other communication tools. Regulatory resources refer to the mandate to pass laws and regulations that control both permitted and prohibited behaviour; while enforcement resources refer to the state mandate to use security and law enforcement agencies to implement and enforce laws.

Ohman's conceptualisation of public resources finds concurrence in the approach by Matlosa and Mbaya (2004, pp. 13-14), who assert that state or public resources refer to 'capabilities (in the form of institutions, human capital, financial wherewithal, technological inputs or other non-material assets) used to achieve set goals of an organisation or a nation'. These approaches indicate that public resources cover considerable breadth, and it is important to adopt an equally broad perspective. However, the discussion in this paper revolves around the use of public media, state security apparatus, public service and state assets (Mbaya 2004, pp. 67-68).

Insofar as access to public resources during elections is concerned, the danger arises when incumbents manipulate their access in order to remain in power. The abuse of public resources, therefore, is the use of public resources to support or undermine a political actor, be it a political party or a candidate (Ohman 2011, p. 1). This abuse encompasses any use of publicly-owned resources in a way that 
affects the operation of political parties or electoral processes to favour certain political actors (Transparency International 2017).

The (ab)use of public resources during elections is commonplace (Speck \& Fontana 2011, p. 1) and is one of the most important and recurrent challenges facing many countries (Venice Commission \& OSCE/ODIHR 2016). While this (ab)use may be aimed at securing re-election, it is not necessarily limited to the campaign period. It may persist for much longer in order to finance political parties and maintain support networks.

The (ab)use of state resources has a corruptive influence on electoral processes since it introduces or exacerbates power imbalances in favour of incumbents (Ritchie et al. 2017, p. 1). The (ab)use of public resources during elections takes many forms. These include the abuse of public infrastructure, diversion of public funds to political parties, manipulating state communication, politicisation of public servants, trading votes for access to public services, and extorting donations from the private sector (Speck \& Fontana 2011, pp. 3-9). While the harmful effects of the (ab)use of public resources during elections are often recognised, few countries have enacted laws for its regulation, and as a result there are loopholes which can easily be exploited (Ritchie et al. 2007, p. 2; Venice Commission 2012). The effect of this (ab)use is to drain the limited funds available for development, infrastructure, or social welfare projects. Conversely, infrastructure projects may be launched around the campaign period to influence voters, rather than being initiated when they are needed (Ritchie et al. 2007, p. 1).

Wahman and Seeberg (2020, p. 4) assert that money matters in an election in multiple ways. For example, in elections with low levels of information, voters tend to support candidates with a higher chance of winning. Candidates need to showcase their viability and credibility if they are to appear to have a fair chance of winning, and this in turn requires them to spend money. Candidates also need money for the logistics of soliciting votes. Money also tends to be more significant in the electoral politics of poor countries like Malawi, with a challenging geography and infrastructure, since candidates will need more resources to manage their campaigns (Helle \& Rakner 2014, p. 162).

The influence of money in elections, however, is not all nefarious as money can have an enabling role in elections by enhancing citizen participation (Speck 2013, pp. 13-20). Political parties, a critical component in any democracy, require money to manage their operations - including cultivating active participation of the citizenry in political processes. It is the unregulated role of money in elections that has the potential to distort competition, create an uneven playing field and undermine public trust in the political system (International IDEA 2017, pp. 124-149). 
In Malawi political campaigns are heavily dependent on rallies, so candidates must have sufficient funds to pay for transporting supporters, hiring public address systems and buying promotional materials (Wahman \& Seeberg 2020, pp. 5). If controlling the state is the only sure way to economic prosperity and power, the incentive to use state resources to remain in office is very high (Helle \& Rakner 2014, p. 168). In addition, because economic activity is centred around the state, incumbent parties and their candidates tend to have a disproportionate advantage stemming from their access to various state resources (Ohman 2016, p. 7). Although incumbency tends to create challenges every where, these challenges are heightened where the incumbent makes little effort to separate partisan acts from state functions. Persistent (ab)use of public resources during elections threatens the consolidation of democracy because it can deform the expression of the will of the people and undermine the very purpose of holding elections (Helle \& Rakner 2014, p. 162).

In the context of an electoral cycle, the regulation of electoral campaigns should guarantee the freedom of all candidates and parties to communicate with the electorate (Rakner \& Svasand 2005, p. 7). This has at least three key aspects: first, state-controlled media should present political alternatives in a neutral fashion; second, all contestants should be afforded an equal opportunity to publicly canvass for votes; and third, access to public resources for campaigning should either be equally available to all candidates or not available at all. This helps to level the playing field.

The (ab)use of public resources during elections undermines fundamental democratic values (Council of Europe [CoE] 2018, pp. 7-8). Three imperatives illustrate these dangers:

- First, elections should be organised in such a manner that neutrality and impartiality are not compromised;

- Second, candidates and political parties ought to be treated equally in relation to all public resources; and

- Third, voters must be free to form an opinion and should not be pressured or induced to vote for particular individuals or political parties.

In many countries, the responsibility for dealing with the (ab)use of public resources during elections falls on election management bodies (EMBs). However, this responsibility is often shared with other agencies. While the Malawi Electoral Commission (MEC) bears the primary responsibility for monitoring the (ab) use of resources during elections, this responsibility is shared with the Malawi 
Communications Regulatory Authority (MACRA) and in some instances with the Anti-Corruption Bureau (ACB).

\section{The Law and the (Ab)use of Public Resources during Elections in Malawi}

Malawian law has standards intended to preserve the integrity of elections. The primary source of such norms is the Constitution, section 5 of which establishes it as the supreme law of Malawi. A reflection on the entire electoral cycle, however, is necessary to understand the relevance of the Constitution to the question of the (ab)use of public resources during elections. Several constitutional provisions are relevant: section 6 of the Constitution provides that the authority to govern derives from the people of Malawi as expressed through universal and equal suffrage in elections held in accordance with this Constitution in a manner prescribed by an Act of Parliament'. Further, section 12 of the Constitution highlights key principles that underlie the system of governance in Malawi, including the fact that all legal and political authority of the state derives from the people of Malawi and must be exercised in accordance with the Constitution (section 12(1)(a)). Section 12(1)(c) emphasises that the authority to govern is conditional upon the sustained trust of the people of Malawi which can only be maintained 'through open, accountable and transparent Government and informed democratic choice'. According to the High Court of Malawi in Saulos Klaus Chilima et al v Arthur Peter Mutharika et al (Constitutional Reference No. 1 of 2019, HC, LL) 'genuine, credible, transparent, free and fair elections form the solid foundation for [Malawi's] pluralist democratic system. Those vested with the duty to conduct elections, therefore, have a sacred duty and responsibility to all the people of Malawi.... The Constitution unequivocally confirms the democratic character of the state and also indicates the role that elections must play in preserving democracy. Since the duty to hold free and fair elections stems from the Constitution, it is arguable that any conduct undermining it is unconstitutional.

Section 193 of the Constitution guarantees the independence and impartiality of the civil service. Under section 193(1), members of the civil service must not compromise their independence and impartiality through their exercise of the right to participate in political activities. Further, under section 193(4), no government or political party should cause any civil servant to 'deploy resources, whether they be financial, material or human resources, for the purposes of promoting or undermining any political party or member of a political party or interest group...'. Section 193, although seemingly limited to civil servants, provides a clear indication of the general proscription against the use of any public resources during electoral activities. Additionally, under section 58 of the Parliamentary and Presidential Elections Act (PPEA) 'every public officer and 
public entity or authority shall give and be seen to give equal treatment to all political parties to enable each political party to conduct its campaign freely'. The emphasis in this provision is on the neutrality of public officers.

In terms of access to public media, section 63 of PPEA is pertinent. Under this provision, all political parties have the right to have the substance of their campaign propaganda reported on television and radio broadcasts by the Malawi Broadcasting Corporation (MBC). Although the MBC has latitude to professionally determine news content, it must maintain neutrality in its reporting and commentary. The responsibility for monitoring news broadcasts, for purposes of ensuring equality among the political parties, is bestowed on the Electoral Commission.

MACRA has a pivotal role in terms of regulating the media. The Communications Act (2016) requires broadcasters to ensure equitable treatment of political parties and candidates during any election period (Rule 32, Second Schedule). MACRA is also empowered to monitor compliance by broadcasters, with terms and conditions attached to any broadcasting licence and also a code of conduct for broadcasting services. The Communications Act has arguably conferred adequate powers on the MACRA to police the use of the media during elections.

The Political Parties Act (Act No. 1 of 2018) also has relevant standards on the (ab)use of public resources during elections. For example, its section 27(3) states that a political party is not eligible to receive donations from state-owned corporations, and section 41(1) prohibits the use of handouts by political parties or candidates. Under this Act, handouts are defined as 'transactions whereby political parties, bodies, candidates or any other person distribute private goods, cash, gifts and other items to a person as an enticement to vote for the political party or the candidate that shall not include matters or transactions specified in the Schedule'. Under the schedule, campaign materials, unpublicised religious obligations or offerings and facilitation of political party meetings or activities such as transport refunds, meals for entourage or entertainment are excluded from the definition of handouts. Section 41(5) of the Act envisages that the responsible minister, the MEC, political parties and other stakeholders will adopt regulations to govern the prohibition of handouts. However, these regulations have yet to be adopted.

The above survey demonstrates that there are legal standards that can be utilised to regulate the (ab)use of public resources during elections in Malawi. There is also unlimited original jurisdiction conferred on the High Court by the Constitution to hear and determine any civil and criminal matters (section 108 Constitution). The courts are therefore the natural and legitimate arbiters of all disputes pertaining to the (ab)use of public resources during elections. 


\section{THE (AB)USE OF PUBLIC RESOURCES DURING ELECTIONS IN MALAWI}

The (ab)use of public resources during elections has been a recurrent issue in Malawi (Patel 2010; European Union Election Observation Mission [EUEOM] 2019 , p. 5). The prevalence of these allegations points to a deep-rooted problem. In this section, the paper principally relies on selected reports by election observer missions to assess the prevalence of this problem.

The 1994 general elections were the first truly competitive elections in post-independence Malawi. The Commonwealth Observer Group's report (1994, pp. 9-18) paints a fair picture of the situation at the time. Notably, Malawi's media had just emerged from three decades of promoting the government's view and that of the Malawi Congress Party (MCP). The result was that the MBC had become a powerful propaganda tool for the one-party state. Initially, the broadcaster made no effort to give a fair and balanced coverage to all political parties (International Commission of Jurists 1994, p. 13). However, as part of efforts to level the playing field, the MEC adopted guidelines for media coverage which required the MBC to provide fair and balanced coverage to all political parties. As a result, the MBC 'transformed its news and current affairs programmes into a form few Malawians could recognise' (Commonwealth Observer Group 1994, p. 15). The MBC, however, was not always even-handed and it sometimes gave preferential treatment to the MCP. The MCP was also accused by opposition parties of (ab)using public resources for campaigning (Commonwealth Observer Group 1994, p. 18).

Campaigning for the 1999 general elections revealed a situation skewed in favour of the incumbent United Democratic Front (UDF) party (Rakner \& Svasand 2005, p. 7). The MEC failed to remedy this biased coverage (Khembo 2005, p. 10). Ironically, less than two weeks before polling day the MEC issued guidelines for the media coverage of elections directed particularly at the MBC. These guidelines were meant 'to ensure that full, fair and balanced coverage is given, without censorship, in all news and other broadcast output relating to the campaigns of all registered candidates and parties during the period of campaigning' (EISA 2002). However, the guidelines were issued late and had negligible effect. Overall, the 'UDF and the State President used state resources, including government vehicles, to conduct its campaign' (Rakner \& Svasand 2005, p. 8). The state security establishment was also co-opted in the UDF's campaign.

According to Khembo (2005, p. 20), 'political campaign strategies during the 2004 elections included handing out money, maize, clothing, bicycles, sugar and salt to the electorate'. MACRA and the MEC failed to coordinate their activities, allowing the public media to favour the incumbent UDF without sanction (Khembo 2005, pp. 44-45; Rakner \& Svasand 2005, p. 7). Concern regarding the 
(ab)use of state resources for campaigning was widespread and 'it did not end with the ruling party's monopoly over state electronic media but included the use of government vehicles, including those of the Electoral Commission, for party activities, the use of parastatal funds for campaigning, the deployment of government personnel and the abuse of the police' (Khembo 2005, p. 47; Rakner \& Svasand 2005, p. 8). The African Union Observer Mission also bemoaned the persistent culture of handouts by political parties (2004, p. 15).

In the 2009 general elections there was a glaring imbalance in resources between the incumbent Democratic Progressive Party (DPP) and other political parties. There was evidence of 'an inordinate exploitation of the incumbency advantage, relating to the use of state institutions, facilities, security services, vehicles and other resources as well as state media' (Commonwealth Observer Group 2009, pp. 18-19). Public media overwhelmingly favoured the DPP in total disregard of all laws stipulating equality among contestants (EISA 2009, p. 15). In a blatant partisan act, MACRA (a government parastatal corporation) was implicated in the abuse of public resources when it printed posters and T-shirts for the DPP (Chinsinga 2010, p. 65).

The Peoples Party (PP) was in power during the 2014 general elections. Notwithstanding the power turnover, the patterns for (ab)use of public resources during elections continued. For example, the $\operatorname{EUEOM}(2014$, p. 19) noted that the ruling PP clearly had an advantage over the three main opposition political parties as it benefitted from the advantages of the incumbency including more stateowned media coverage'. The PP also engaged in the distribution of handouts such as maize, bicycles, blankets, motorbikes and construction equipment (EUEOM 2014, p. 20). In terms of access to state media, 'the PP dominated the airtime on both state-owned radio and television' (EUEOM 2014, p. 23). In addition, the PP made little effort to separate its campaign activities from state functions.

By the time the 2019 general elections were being held a new Political Parties Act was in place, though not fully in force. Notwithstanding the proscription of handouts in section 41 of this Act, the use of handouts by political parties was recurrent (African Union Election Observation Mission [AUEOM] 2019, pp. 17-18). Complaints about unequal media coverage also arose, especially from opposition political parties. As noted by the $\operatorname{AUEOM}(2019$, p. 17) 'despite the legal restrictions on the use of state resources and bias of state media, these provisions were violated by some political parties without repercussion'. The 'campaign was marked by the misuse of handouts and the abuse of state resources and incumbency' (EUEOM 2019, p. 2).

In a judgment delivered in February 2020 the High Court of Malawi nullified the 2019 presidential election which was found to have been affected by irregularities. In May 2020, the Malawi Supreme Court of Appeal upheld the 
High Court's judgment confirming that fresh elections had to be held. The new elections, held in June 2020, revealed (ab)use of public resources. Strikingly, this (ab)use was not limited to the incumbent DPP but extended to the opposition Tonse Alliance because the incumbent vice-president ran for office on the same ticket as the then leader of the opposition. The result was that both the sitting president and the vice president had access to public resources in support of their campaigns. The most blatant act of abuse, however, occurred when the DPP formed an alliance with the UDF and accorded the UDF president, the alliance's running mate, privileges akin to those of the state vice-president: government vehicles, state security and a lion's share of the public media coverage.

Despite the turnover of power, the persistent (ab)use of public resources confirms that incumbency tends to precede the (ab)use of state resources in elections. It is also clear that this (ab)use often happens in an environment where it has recurred over decades of elections (CoE 2016). The (ab)use of state resources during elections in Malawi is arguably also a reflection of the enduring effects of neo-patrimonialism where the state is considered a resource to be distributed among loyalists.

\section{JURISPRUDENCE REGARDING THE (AB)USE OF PUBLIC RESOURCES IN MALAWI'S ELECTIONS}

While Malawian elections have generated countless judicial determinations, there are few cases dealing specifically with the (ab)use of public resources during elections. Almost all cases on the subject relate to incidents occurring during the campaign period. Under section 57 of the PPEA, 'the period of campaigning in public by every political party ... shall be a period of two months closing forty-eight hours before the opening of the poll.... Because of this restriction, the advantages of public resource $(\mathrm{ab})$ use tend to become more obvious and thus more readily trigger a reaction from political actors during the campaign. Absent the exigencies of an impending election, political actors have not attempted to challenge the (ab)use of public resources.

One of the earliest cases is Dr Charles Kafumba et al v Malawi Electoral Commission et al (the Kafumba Case) (Miscellaneous Civil Cause No. 35 of 1999 HC, PR) which arose in the run-up to the 1999 general elections. The petitioners complained that the MBC had failed to provide equal access to all political actors and had favoured the then incumbent UDF. The petitioners had previously filed the same complaint with the EC which made no effort to resolve their grievances. The Court confirmed that the Communications Act required that political parties be treated equally in terms of their access to public media. After assessing the various mechanisms put in place by the EC to ensure equitable access to the public media, 
the Court concluded that the EC had done enough to comply with the law. The Court held, however, that the MBC had failed to accord equitable access to all political actors. It also held that the primary responsibility for ensuring equitable access to public media lies with MACRA. The Court directed the MBC to work with MACRA to ensure non-discriminatory access to public media.

The case of National Democratic Alliance v Electoral Commission et al (the NDA Case) (Constitutional Cause No. 3 of 2004, HC, PR) arose during the 2004 general elections. The NDA Case was factually so similar to the Kafumba Case that the High Court noted: 'that the present case is virtually just a reincarnation of the Kafumba case'. This case was dismissed on procedural grounds. The Court found that the applicant had breached the civil procedure rules by unilaterally abridging the time within which the respondents were meant to respond to the originating summons. The Court also found that the applicant's affidavit was defective since it did not attach any evidence in support of the claims. Gloppen et al. (2006, p. 36) contend that the Court erred in dismissing the case on technical grounds and it should have adopted 'a more creative and less formalistic approach', including taking judicial notice of publicly available documentation. This argument, however, ignores the adversarial character of the court system in Malawi, and surreptitiously places the onus on the court to look for evidence in support of a party's case. While courts should be urged not to be unduly bogged down by technicalities, especially in matters of public interest, this decision was correct given the rather casual manner in which the plaintiffs framed their case.

Another case that arose during the 2004 general elections was The Republican Party (representing its members and all of Mgwirizano Coalition Grouping) v Electoral Commission et al (the Republican Party Case) (Constitutional Case No. 5 of 2004 $\mathrm{HC}, \mathrm{PR})$. The court had to determine whether the MEC was correct in referring a complaint on the (ab)use of public resources by the incumbent president to the Office of the President and Cabinet (OPC) instead of dealing with it. The High Court held that by referring the plaintiffs' complaint to the OPC, the MEC abdicated its duties under the Constitution and the PPEA because the law confers on it wide powers to resolve any complaint related to the conduct of elections.

On appeal to the Malawi Supreme Court of Appeal (MSCA), the findings of the High Court, in relation to the Electoral Commission's failure to control the abuse of public resources by the incumbent, were confirmed (The Malawi Electoral Commission and others $v$ the Republican Party MSCA Civil Appeal No. 14 of 2004). The MSCA held that 'the 1st Appellant erred in referring the complaint on this aspect to the Office of the President and Cabinet, instead of dealing with it itself as required both under the Constitution and statutory law'.

The last case is Loveness Gondwe et al $v$ Catherine Gotani Nyahara (the Loveness Gondwe Case) (MSCA Civil Appeal No. 2 of 2005). This was an appeal from a 
High Court decision which had invalidated a parliamentary election (Catherine Gotani Nyahara v Loveness Gondwe and another Miscellaneous Civil Cause No. 82 of $2004 \mathrm{HC}, \mathrm{MZ}$ ). One of the irregularities established by the High Court was that the appellant, who was a first deputy speaker of the National Assembly at the material time, had used her official government vehicle during the campaign. The MSCA held that the appellant was entitled to use her official vehicle, for both official and private business, even after the dissolution of the National Assembly by virtue of both the Constitution and the Parliamentary Service Act (section 10).

The MSCA made two key findings. First, that the respondent had failed to prove 'by evidence what effect the use of the vehicle had on the election result', and therefore failed to demonstrate that the appellant would have lost the election but for the use of the official vehicle. Second, that '... both the Constitution and the PPEA are silent on the use of public resources for campaign purposes... and any judicial findings that such use is unconstitutional ... are not entirely correct...'.

Although the MSCA found that there had been irregularities in the conduct of the parliamentary election at issue, it held that these had not affected its outcome, and therefore upheld the appeal and reversed the High Court's order nullifying the result. The MSCA has subsequently modified the position in the Loveness Gondwe Case and endorsed an approach that utilises both the quantitative and qualitative aspects to proving irregularities necessitating the nullification of an election - Prof Arthur Peter Mutharika et al v Dr Saulos Klaus Chilima et al (MSCA Constitutional Appeal No. 1 of 2020).

\section{PUBLIC RESOURCES AND ELECTIONS IN MALAWI}

\section{An Analysis of Selected Issues}

All elections in Malawi since 1994 have revealed that the MEC and other key stakeholders have been challenged in terms of facilitating fair electoral processes (Rakner \& Svasand 2005, p. 7). While the challenges have been multifarious, one of the persistent challenges has been the (ab)use of public resources, especially by incumbents. It must be recalled, however, that 'the underlying principle in respect of the law of elections in Malawi is that elections must be free and fair' and that it is the duty of the MEC to 'not only ensure that elections are free and fair but to adopt measures to guarantee that elections are indeed free and fair' (Catherine Gotani Nyahara v Loveness Gondwe et al. HC, MZ). The '[Electoral] Commission, therefore, has the singular duty under the Constitution as well as under all relevant statutes, to conduct elections that are ultimately free and fair' (Prof Arthur Peter Mutharika et al $v$ Dr Saulos Klaus Chilima et al. (MSCA Constitutional Appeal No. 1 of 2020). From a legal perspective, it must be recalled that the law has granted the 
MEC considerable leeway in terms of the precise steps that it can take to ensure that elections are free and fair.

\section{The Perennial Contest over Access to State Media}

Access to the media is critical in determining whether or not elections are free and fair. Equitable access to the media allows contestants a fair opportunity of conveying their message to potential voters, which in turn allows voters to exercise informed choices. The quality of a democracy is improved when voters exercise informed choices (Centre for Multiparty Democracy 2020, p. 39).

Although all public resources in Malawi are at risk of abuse during elections, state media is the resource most highly susceptible to abuse and has been monopolised by incumbents in all electoral cycles. Ironically, state media seems to have performed better in the 1994 general elections during the transition from a one-party state. After 1994, the situation deteriorated and stagnated. Patel (2009) asserts that the performance of the state media in the 2009 general elections was so glaringly biased that it probably ranked as the worst-ever performance by the state media during an election in Malawi. In the 2004 elections access to state media was also heavily contested, resulting in litigation before the High Court. Access to state media is critical in Malawi since it has huge coverage across the country. The perennial monopolisation of state media by incumbents inevitably creates an uneven playing field, thereby undermining free and fair elections.

In the Kafumba Case, the High Court considered whether the MEC had taken due steps to guarantee all political parties equal access to state media, and concluded that '...the Commission [had] done everything under their mandate ... the Commission cannot take over the running of Malawi Broadcasting Corporation'. The Court made this finding because the MEC proved that it had made arrangements with the $\mathrm{MBC}$ to broadcast campaign messages for all political parties. It also proved that it had convened a meeting with the MBC to impress on them the need to accord equal access for all contestants to state media. The failure, therefore, was due to MBC's recalcitrance. The Court also noted that the law has not granted the MEC the means to enforce its directives about equal coverage on state media.

The 2004 and 2009 general elections are further proof of the challenges faced by the MEC in ensuring equitable access to state media. In the run-up to the 2004 elections, the MEC established a media monitoring unit. This notwithstanding, state media heavily favoured the incumbent. Further, although a Media Code of Conduct was adopted for the 2009 elections enjoining all media houses to be balanced and impartial, the patterns from 1999 and 2004 were replicated. The MEC failed to enforce the Media Code of Conduct (Commonwealth Secretariat 2009, p. 21). 
A critical look at the prevailing regulatory framework reveals that both MACRA and the MEC have a role in ensuring that political actors are granted equitable access to public media. In practice, however, the allocation of responsibilities between MACRA and the MEC is not clear. Coupled with the absence of a clear sanctions regime, the enforcement of neutrality is compromised. This, therefore, is an area in need of law reform.

\section{Public Resources and the Campaign Period}

As earlier noted, section 57 of the PPEA prescribes the campaign period as two months ending forty-eight hours before polling, ostensibly the period within which political actors can canvass for votes. The challenge is that 'political campaigns continue to take place, under various forms and guises, even outside the specified campaign period' (Malawi Law Commission 2017, p. 114). Neither the PPEA nor any other law has provided clarity as to whether the MEC, or any other entity, has the power to receive complaints about campaigning outside of the period prescribed by the PPEA (Malawi Law Commission 2017, p. 115). Incidents of (ab)use of public resources tend to increase during the campaign period.

A key contributing factor in the (ab)use of public resources for elections by incumbents in Malawi is the failure to maintain a clear demarcation between state functions and party activities (Centre for Multiparty Democracy 2020, p. 41). This lack of clarity has been exploited by incumbents to arrogate to themselves advantages which other competitors do not have. These include the use of state security and government vehicles and also direct financial support from parastatal corporations. For example, the president could, on paper, undertake a state function such as the commissioning of a road project, and at the same time, address a 'development rally', which would be nothing short of overt campaigning. During such a rally the president would also disburse all manner of merchandise, including cash, to supporters. No clarity has emerged as to the source of the items that presidents have traditionally distributed.

So far, judicial challenges relating to the (ab)use of public resources for elections have been lodged in relation to activities happening during the designated campaign period. For example, the NDA Case started about a month before polling in 2004. During these elections the MBC and TV Malawi had been biased since the early stages of the electoral cycle (Gloppen et al. 2006, p. 36). This begs the question as to why the judicial challenge was launched late in the electoral cycle. It appears that the litigants may have assumed that lodging the case before the designated two-month campaign period would be premature and lead to automatic failure (ibid.).

The plaintiffs' conduct in the NDA Case is revealing. First, it is clear that the designation of a two-month campaign period is pointless. Political actors 
in Malawi actively campaign throughout the electoral cycle. The result is that unfair advantages can be acquired at any point during the electoral cycle and not simply during the two months preceding voting. In principle, therefore, the (ab) use of public resources by an incumbent can be challenged at any point during the electoral cycle. Given the excesses of the regime in 2004, it was ill-advised for the plaintiffs in the NDA Case to wait until two months before polling before commencing their action.

Second, Gloppen et al. (2006, p. 36) contend that the failure to act expeditiously by the petitioners in NDA Case was also influenced by their pessimism about the ability of courts to change the biased coverage of the MBC. The petitioners may have been reinforced by the MBC's disregard of the 1999 judgment in the Kafumba Case. Several reasons explain government non-compliance with court orders (Kanyongolo 2006, pp. 51-54). Sometimes non-compliance is due to a lack of resources but it can also be due to premeditated actions, especially by the executive. Generally, it seems that government's compliance depends on the subject matter of the court order. The government will thus be slow to comply with orders where it stands to lose politically, while it is often more amenable to complying with orders that have limited political repercussions. Considering the centrality of state media to elections in Malawi, it is unsurprising that court orders meant to guarantee equitable access have been ignored by successive incumbents.

\section{Narrow judicial understanding of public resources}

The judgment in the Loveness Gondwe Case, being a decision of the most superior court in Malawi, deserves special attention. Under the doctrine of stare decisis, all courts below the MSCA are bound to apply this judgment unless they can distinguish it. The MSCA found that although the appellant had used her official vehicle during campaigning this did not amount to an abuse of public resources. Gloppen et al. (2006, p. 38) are correct in asserting that the MSCA's judgment could be interpreted as a blanket authorisation for incumbents to utilise public resources for campaign purposes. The MSCA's findings are cast in wide terms suggesting that the use of public resources in elections is not restricted.

The rather bland findings by the MSCA can be explained by its later comments in the same judgment in which it found that both the Constitution and the PPEA are 'silent on the use of public resources for campaign purposes'. The silence that the MSCA alludes to is hard to fathom. In Malawi, free and fair elections are decreed by the Constitution. Abuse of public resources has the potential of distorting the playing field for contestants, which in turn undermines the integrity of elections. On the basis of the Constitution alone, the MSCA could have made an emphatic statement about the impropriety of the abuse of public 
resources for campaigning. Additionally, the PPEA provisions meant to guarantee, for example, equitable access to state media (another public resource), should have inspired the MSCA to appreciate the general scheme meant to guarantee free and fair elections.

The MSCA's findings may arguably have been influenced by the nature of the public resource at issue in the Loveness Gondwe Case - an official motor vehicle, which is often allocated for the use of a specified individual with latitude to cover both private and official uses. The proscription on the use of public resources during elections, however, must be understood to cover all forms of public resources, with the defining trait being whether or not such use confers an advantage not extended to other contestants.

The MSCA's struggles in the Loveness Gondwe Case do not seem to be isolated. The Special Law Commission on the Review of Electoral Laws, which considered the question of the (ab)use of public resources in elections, also struggled with this issue (Malawi Law Commission 2017, pp. 115-117). While the Special Law Commission proposed that the use of public resources for campaigning should be banned, two situations were distinguished. The first scenario was where a public resource, such a car, is given for a public official's use as part of his or her entitlements. The Special Law Commission found that if the official subsequently used such a car for campaigning he or she should not be deemed to have abused public resources. Unsurprisingly, the Special Law Commission referred to the Loveness Gondwe Case to buttress its recommendation. The second scenario is where a public official commandeers public resources which are not part of his official entitlements, for campaign purposes. In the latter scenario, the Special Law Commission recommended that sanctionable abuse of public resources should exist.

The judgment in the Loveness Gondwe Case and the recommendations of the Special Law Commission are problematic. The MSCA's judgment, because of its blanket language, can be interpreted to suggest that there are no restrictions on the use of public resources for campaigning. The MSCA's failure to explore the nuances as to when an incumbent's use of public resources can cross the line of legitimate use is regrettable. Key here, however, would be the determination of when the use of public resources confers an advantage that other contestants do not have, which advantage cannot rationally be justified as a legitimate consequence of incumbency.

The MSCA in the Loveness Gondwe Case also relied on the fact that 'the extent of the use of the official vehicle during campaign was not established'. According to the MSCA, the effect that the use of the vehicle had on the outcome of the election had not been proved. This, however, was tantamount to setting an unrealistic standard. It should be recalled that while it may be easy to spot incidents of (ab)use 
of public resources, it is very difficult for would-be petitioners to prove the same (Helle \& Rakner 2014, pp. 163-165). This is partly because such abuse is often perpetrated by incumbents, making it very difficult for law enforcement agencies to act, especially in emerging democracies with weak supervisory institutions (Sample 2017, pp. 24-25). Since then the MSCA has partly clarified the issue by adopting both a qualitative and quantitative test in assessing evidence alleging electoral malpractice - Prof Arthur Peter Mutharika et al v Dr Saulos Klaus Chilima et al. (MSCA Constitutional Appeal No. 1 of 2020).

\section{The Regulation of Political Party Funding}

A sound system for regulating campaign and political party finance is a central tenet for democratic elections and can assist with stemming (ab)use of public resources (The Congress and Council of Europe 2016). In Malawi, however, no framework for dealing with accountability for party funding existed before the adoption of the Political Parties Act of 2018 (Khembo 2005, p. 32). The result was that there was no statutory obligation on political parties to disclose the sources of their funding or to account for the use of party funds. The Political Parties Act requires political parties to declare to the Registrar of Political Parties any donation of at least MK1 000000 from an individual, and any donation of at least MK2 000000 from an organisation, within 90 days of receipt (section 27). The Act also requires all political parties that receive private funding to keep financial records which must be audited by a certified public accountant (section 30). State funding of political parties is covered under section 40(2) of the Constitution but extends only to political parties that garner at least one-tenth of the national vote in a general election. In practice, many small political parties are automatically excluded since they are unable to garner these votes.

The improvements introduced by the Political Parties Act notwithstanding, the framework regulating the financing of political parties remains problematic. For example, there are no restrictions on the sources of private funding to which political parties can have access. In practice, Malawian political parties rely on funding from well-wishers, membership contributions and patrons or financiers. The reliance on patrons or financiers, however, exposes them to undue influence by major funders. Additionally, there are no ceilings to campaign expenditure by political parties, which results in major discrepancies in the resources of the various political parties (EUOM 2014, p. 19). These arrangements favour the bigger and more established political parties over the small emerging parties.

Uncontrolled, undisclosed and opaque political financing is a threat to the integrity of elections and has a corruptive influence on the management of political parties (Helle \& Rakner 2014, p. 165; Matlosa 2004, p. 8). It provides undue influence to a clique of individuals and obliterates the need to focus on the common good, 
while also creating an uneven playing field. Unregulated political party funding poses a triple threat to democracy since it fosters political inequality, engenders corruption and contributes to the loss of democratic accountability (EISA 2014, pp. 8-10). In respect of a political party in power, for example, a murky legislative framework regarding political party funding creates opportunities for the abuse of public resources and conceals detection of the same.

While the innovations introduced by the Political Parties Act 2018 are commendable, it is clear that more needs to be done to bring about transparency and accountability in respect of the funding of political parties. The challenge with regulating political party funding, however, is not simply due to the absence of a governing law; but rather one of implementation (Ohman 2016, pp. 9-11). More, therefore, needs to be done beyond the adoption of the Political Parties Act.

\section{The Role of Civil Society}

Civil society organisations (CSOs) have always undertaken critical roles during elections in Malawi. For example, they have collaborated with the MEC to conduct civic and voter education and also provided monitors and observers in elections. The parallel voter tabulation managed by the Malawi Electoral Support Network remains one of the pivotal contributions of civil society in electoral processes.

CSOs can play a critical role in monitoring the (ab)use of public resources during elections, though regrettably, Malawian CSOs have not done very well on this score. This could be due to an over-focus on election day activities such as monitoring and observation at the expense of other activities during the electoral cycle. CSOs, however, can monitor campaign spending by political parties and in the process reveal whether political parties and candidates are adhering to laws on political financing, and also whether the regulatory bodies are objectively enforcing the regulatory framework (TIDE 2013, p. 119). CSOs can also monitor the use of state resources by incumbents to determine abuse. It is important, therefore, to harness the potential of CSOs in order to enhance the integrity of electoral processes.

The NDA Case, previously discussed, was originally filed by the Public Affairs Committee (PAC), an umbrella body for religious organisations. Although the PAC subsequently abandoned the case, its initial involvement was an encouraging sign about the role that CSOs can play in monitoring the abuse of public resources during elections. CSOs should, therefore, consider strategic litigation as a tool for levelling the playing field during elections.

Transparency, freedom of expression and information remain important in stemming the abuse of public resources during elections (Venice Commission \& 
Council of Europe 2012). CSOs can also raise public awareness of the activities of political parties, particularly the ruling party. Availability of information has the potential to undermine the abuse of public resources and dilute the traditional advantage that incumbency confers (MacDonald 2014, pp. 22-23). In addition to raising public awareness CSOs should also be at the forefront in advocating for reforms in the regulatory framework.

\section{CONCLUSION}

The major challenge in dealing with (ab)use of public resources during elections is that most of the (ab)use is committed by those in power. Countering this (ab)use, therefore, requires the existence of a clear regulatory framework and robustly independent institutions. The judiciary is a natural option in this regard. In practice, the use of public resources during elections suggests bias in favour of incumbents. Courts in Malawi have traditionally played a critical role in resolving disputes that have arisen during the electoral cycle. However, the judicial pronouncements on the (ab)use of public resources during elections are sparse and uninspiring. Given the rather sketchy legislative framework regulating the use of public resources during elections in Malawi, courts retain a pivotal role in demarcating permissible usage of state resources and also assisting in clarifying the roles of the enforcement agencies. Given the shortcomings by the courts, other stakeholders, such as CSOs, should also to take a role in monitoring the (ab)use of public resources during elections.

\section{REFERENCES}

African Union 2019, 'African Union Election Observation Mission Report: Malawi 2019', https://au.int/sites/default/files/documents/38117-doc-report_of_ the_african_union_election_observation_mission_to_the_21_may_2019_ tripartite_elections_in_the_republic_of_malawi.pdf, (viewed 29 April 2020).

African Union 2004, 'Report of the African Union Observer Team on the presidential and parliamentary elections in the Republic of Malawi held on 20 May 2004' http://aceproject.org/ero-en/regions/africa/MW/malawi-final-reportpresidential-and-parliamentary-2, (viewed 20 April 2020).

Catherine Gotani Nyahara v Loveness Gondwe and another, Miscellaneous Civil Cause No. 82 of 2004, HC, MZ.

Centre for Multiparty Democracy 2020, 'Free and fair elections in Malawi: Towards national level consensus', https://www.cmdmw.org/index.php/documents/ 
publications/4-free-and-fair-elections-in-malawi-towards-national-levelconsensus/file $+\& c d=12 \& h l=e n \& c t=c l n k \& g l=t z$, (viewed 4 May 2020).

Chinsinga, B 2010, 'A critical stock take of Malawi's 19 May 2009 Elections: Processes, outcomes, challenges', Journal of African Elections, vol. 9, no. 1, pp. 54-79.

Commonwealth Secretariat 1994, 'The parliamentary and presidential elections in Malawi 17 May 1994: The Report of the Commonwealth Observer Group', Commonwealth Secretariat, London.

Commonwealth Secretariat 2009, 'Malawi parliamentary and presidential elections 19 May 2009: Report of the Commonwealth Observer Group', http://aceproject. org/ero-en/regions/africa/MW/malawi-final-report-parliamentary-andpresidential-1, (viewed 29 April 2020).

Congress of Local and Regional Authorities 2016, 'The misuse of administrative resources during electoral processes: The role of local and regional elected representatives and public officials', Council of Europe, https://rm.coe. int/168071a562, (viewed 8 September 2020).

Congress of Local and Regional Authorities 2018, 'Administrative resources and fair elections: A practical guide for local and regional politicians and public officials', Council of Europe, https://rm.coe.int/168071a562, (viewed 10 March 2020).

Dr Charles Kafumba et al v Malawi Electoral Commission et al (Miscellaneous Civil Cause No. 35 of 1999 HC, PR).

Dr Saulos Klaus Chilima et al v Prof Arthur Peter Mutharika et al (Constitutional Reference No. 1 of 2019, HC, LL).

Electoral Institute for Sustainable Democracy in Africa (EISA) 2009, 'Election observer mission report: The Malawi presidential and parliamentary elections of 19 May 2009' https://www.eisa.org/pdf/mal2009eomr.pdf, (viewed 29 April 2020).

Electoral Institute for Sustainable Democracy in Africa (EISA) 2014, 'South Africa 2014 election update. Resources: state and private - use or abuse?' https:// www.eisa.org/eu/pdf/electionupdate5.pdf, (viewed 3 September 2020).

European Election Observation Mission, 'Malawi: Tripartite elections 21 May 2019: Preliminary statement' http://www.eods.eu/library/preliminary_ statement_eu_eom_malawi_2019.pdf, (viewed 29 April 2020).

European Union Election Observation Mission, 'Final report: Malawi 2014' http:// eeas.europa.eu/archives/eueom/missions/2014/malawi/pdf/eueommalawi2014-final-report_en.pdf, (viewed 29 April 2020).

Gloppen, S, Kanyongolo, E, Khembo, N, Patel, N, Rakner, L, Svasand, L, Tostensen, A \& Bakken, M, 2006, 'The institutional context of the 2004 General Elections in Malawi', https://www.cmi.no/publications/file/2541-the-institutionalcontext-of-the-2004-general.pdf, (viewed 20 April 2020). 
Helle, S \& Rakner, L 2014, 'Grabbing an election: Abuse of state resources in the 2011 elections in Uganda' in T Søreide \& A Williams (eds), Corruption, Grabbing and Development: Real World Challenges, Edward Elgar Publishing, Cheltenham.

International Commission of Jurists 1994, 'Parliamentary and presidential elections in Malawi: Report of the team of observers of the International Commission of Jurists April-May 1994', https://www.icj.org/wp-content/uploads/2013/10/ Malawi-elections-mission-report-1994-eng.pdf, (viewed 25 April 2020).

International IDEA 2017, The global state of democracy: Exploring democracy's resilience, https://www.idea.int/publications/catalogue/global-state-democracyexploring-democracys-resilience, (viewed 7 September 2020).

Kanyongolo, E 2006, Malawi: Justice Sector and rule of law, Open Society Foundation, Johannesburg.

Khembo, N (ed.) 2005, 'Elections and democratisation in Malawi: An uncertain process', EISA Research Report, no. 10, https://www.eisa.org/pdf/rr10.pdf, (viewed 10 April 2020).

Loveness Gondwe et al v Catherine Gotani Nyahara (MSCA Civil Appeal No. 2 of 2005). MacDonald, B 2014, 'Estimating incumbency advantages in African politics: Regression discontinuity evidence from Zambian parliamentary and local government elections' https://www.files.ethz.ch/isn/179542/WP151.pdf, (viewed 20 April 2020).

Malawi Law Commission 2017, Report of the Law Commission on the review of electoral laws, Government Printer, Lilongwe.

Matlosa, K \& Mbaya, K 2004, 'An analysis of the utilisation of state/public resources during elections: A comparative survey of experiences in the SADC region'. In K Matlosa (ed.), The politics of state resources. Party funding in South Africa, Konrad Adenauer Stiftung, Johannesburg.

Mbaya, K 2004, 'The use of state resources during elections in South Africa'. In K Matlosa (ed.), The politics of state resources. Party funding in South Africa, Konrad Adenauer Stiftung, Johannesburg.

Matlosa, K 2004, 'Introduction'. In K Matlosa (ed.), The politics of state resources. Party funding in South Africa, Konrad Adenauer Stiftung, Johannesburg.

National Democratic Alliance v Electoral Commission et al (Constitutional Cause No, 3 of 2004, HC, PR).

Ohman, M 2011, Abuse of state resources: a briefintroduction to what it is, how to regulate against it, and how to implement such regulations resources, USAID, Washington, DC. https://www.ifes.org/sites/default/files/georgia_abuse_of_state_ resources_july_2011_0.pdf, (viewed 15 March 2020).

Ohman, M 2016, 'The state of political finance regulations in Africa', International IDEA Discussion Paper, No. 14/2016, https://www.idea.int/sites/default/files/ 
publications/the-state-of-political-finance-regulations-in-africa.pdf, (viewed 7 September 2020).

Patel, N 2010, 'Malawi's 2009 Elections: A Critical Evaluation', Paper for Presentation at the Conference on Election Processes, Liberation Movements and Democratic Change in Africa, Maputo 8-11 April 2010.

Prof Arthur Peter Mutharika et al v Dr Saulos Klaus Chilima et al. (MSCA Constitutional Appeal No. 1 of 2020).

Rakner, L \& Svasand, L 2005, 'Maybe free but not fair: Electoral administration in Malawi 1994-2004', https://www.cmi.no/publications/file/2127-maybe-freebut-not-fair.pdf, (viewed 25 April 2020).

Ritchie, M, Shein, E, Sanderson M, Morgan, B \& Legelee, J 2017, ‘Unfair advantage: The abuse of state resources in elections', Paper, International Foundation for Electoral Systems, 5 April, https://www.ifes.org/sites/default/files/2017_ifes_ unfair_advantage_the_abuse_of_state_resources_in_elections_final_web. pdf, (viewed 15 April 2020).

Ronceray, M \& Byiers, B 2019, 'Elections in Africa - Playing the game or bending the rules?', Discussion Paper, ECDPM, October 2019, https://ecdpm.org/wpcontent/uploads/Elections-Africa-Playing-Game-Bending-Rules-ECDPMDiscussion-Paper-261.pdf, (viewed 4 September 2020).

Sample, K 2017, 'Electoral challenges in Haiti from a comparative perspective', World Leadership Alliance Club de Madrid, http://www.clubmadrid.org/ wp-content/uploads/2017/10/Electoral_Challenges_Haiti_ENGLISH.pdf, (viewed 4 September 2020).

Speck, B \& Fontana, A 2011, 'Milking the system: Fighting the abuse of public resources for re-election', https://www.u4.no/publications/milking-thesystem-fighting-the-abuse-of-public-resources-for-re-election.pdf, (viewed 18 April 2020).

Speck, BW \& Olabe, OB 2013, 'Money in Politics', in OECD Policy Forum Restoring Trust in Government: Addressing Risks of Influence in Public Decision Making, hosted by the Public Sector Integrity Network, OECD, Paris, 14-15 November 2013, https://www.oecd.org/gov/ethics/Money-in-politics.pdf, (viewed 7 September 2020).

The Malawi Electoral Commission and others $v$ the Republican Party (MSCA Civil Appeal No. 14 of 2004.

The Republican Party (representing its members and all of Mgwirizano Coalition Grouping) $v$ Electoral Commission et al. (Constitutional Case No. 5 of 2004 HC, PR).

Training in Detection and Enforcement (TIDE) 2013, 'The Political finance oversight handbook', IFES, https://www.ifes.org/publications/tide-political-financeoversight-handbook, (viewed 4 April 2020). 
Transparency International 2017, ‘Best practice on preventing the abuse of public resources', https://www.transparency.org/whatwedo/answer/best_practice_ on_preventing_the_abuse_of_public_resources [viewed 17 April 2020].

Venice Commission \& OSCE/ODIHR 2016, 'Joint guidelines for preventing and responding to the misuse of administrative resources during electoral processes', https://www.osce.org/odihr/elections/227506?download=true, (viewed 6 May 2020).

Venice Commission \& Council of Europe 2016, 'Preliminary draft report on the use of administrative resources during electoral campaigns' https://www. venice.coe.int/webforms/documents/default.aspx?pdffile=CDL(2012)075-e (viewed 8 September 2020).

Wahman, M \& Seeberg, 2020, 'Ruling party advantages from the top-down or the bottom-up: Unequal campaign spending in Malawian parliamentary elections', Paper presented at the Annual Meeting of the African Studies Association, 21-23 November 2019. 